Research Article

\title{
Export Promotion, Sales and Profits: A Structural Equation Modelling
}

\author{
Ng Kim-Soon, Abd Rahman Ahmad and Chua Pei Shy
}

Faculty of Technology Management and Business, Universiti Tun Hussein Onn, Malaysia

Correspondence should be addressed to: Ng Kim-Soon; ksng@uthm.edu.my

Received date: 9 February 2015; Accepted date: 15 June 2015; Published date: 22 January 2016

Academic Editor: Ng Sin Huei

Copyright (C) 2016. Ng Kim-Soon, Abd Rahman Ahmad and Chua Pei Shy. Distributed under Creative Commons CC-BY 4.0

\begin{abstract}
Export promotion can be a differentiator for sales and profits. More research works are needed to explicitly delve into developing concrete models and multi-dimensional scales to strengthen the theoretical foundations for measuring export performance. This study uses SEM to model on export promotion, firm's quality reputation, product and service quality for generating sales with profit. The respondents were the Johor State manufacturing exporters selected from the Federation of Malaysia Manufacturers Directory based on Krejcie and Morgan sampling plan. Respondents answered a self-administered survey questionnaire. Results indicated that the observable variable of export promotion comprises of management of sales promotion activities, selecting and participating in relevant trade fairs, preparation of product literature, and evaluating channel performance. The latent variables that have loaded highly into enhancing firm's quality are improving products, providing better service quality and gaining reputation. The latent variables of sales performance that loaded in the observable measure of export sales are export sales efficiency and export sales growth. Profits measure was found to comprise of export profitability and profit margin. Structural equation modelling of good fitting has shown that export promotion enhances firm's quality and will lead to higher sales with profits. Future research and practical implications are reported.
\end{abstract}

Keyword: export, export promotion, products, service quality, export performance

\section{Introduction}

Export promotion, a factor of export marketing mix, can be a differentiator for profits. Exporters are using it to inform potential importers of products or services features in order to attract them to buy. Most literature reviews looked at export marketing and export performance in two broad perspectives. The first body of literature studies focuses on investigating the contribution of marketing in firm's export performance, while the second body focuses on the relationship between marketing competencies with organization or venture performance (Kim-Soon, 2005). Few studies (Chugan and Singh, 2014; Zou et al., 1998; Cavusgil and Zou, 1994; and Lages et al.,

Cite this Article as: Ng Kim-Soon, Abd Rahman Ahmad and Chua Pei Shy (2016)," Export Promotion, Sales and Profits: A Structural Equation Modelling", Journal of Southeast Asian Research, Vol. 2016 (2016),

Article ID 309540, DOI: 10.5171/2016.309540 
2004) have dwelled explicitly on developing concrete models and multi-dimensional scales leading to strengthening the theoretical foundations for measuring firm's export performance. For this, there is a need for further exploratory studies to assess more encompassing frameworks of measuring firm's export performance (Chugan and Singh, 2014). Performance measure purposes may be incompatible with each other, where the improvement in one dimension may be a trade-off for the other, success may not be objectively determined but a variable one. Hence, this study has dwelled to understand the relationship of export promotion in the enhancement of firm's quality reputation, product and service quality to generate export sales and profits. The first is a factor from the marketing mix while the latter three measures, firm's quality enhancement, sales and profits are commonly used in export literatures to examine export performance. Most researchers accepted the multidimensionality of export performance used in their research works with disagreement about which measures should be appropriate and common. It is therefore significant to further investigate the role of export promotion, a factor of marketing mix on export performance.

\section{Literature Review}

\section{Export Promotion}

Promotion is about communicating to the targeted customer in an effective and efficient manner through the promoted message of advertising, features and displays. It facilitates consumer's purchasing behaviors (Darke and Dahl, 2003) by providing useful cue for the cognitive evaluations of a product influencing the purchasing decision (Raghubir, 2004). The common methods of promotion are through personal selling done through promotional presentation made on a person-to-person basis with a potential customer and the nonpersonal selling through advertising, sales promotion, and public relations. The
American Marketing Association (AMA) defines a company's total promotion mix as the specific blend of advertising, sales promotion, public relations, personal selling and direct marketing tools that a company uses to persuasively communicate customer's value and build customer relationships (Ehrman, 2011). Export promotion activities may include export sales presentation, participation of trade fairs, trade promotion supports to overseas distributors, preparation of product literature, and managing promotional activities (Kim-Soon, 2005). Okoroafo and Perryy (2010) state that promotion tools can be in the form of magazines, videos, one-onone promotion and online promotion that are available for a minuscule fee. Milanzi (2012) suggested that managers should make use of internet facilities for communication, market intelligence and export performance. Promotional plan can also include product's value added programmes such as repair services and warranty programs.

Export promotion, firm's quality of reputation, product improvement, service quality, sales and profits

Export promotion programmes are aimed at enhancing company export performance through exporter's capabilities, resources, strategies and their overall competitiveness (Shamsuddoha and Ali, 2006; Wilkinson and Brouthers, 2006). The finding by Koksal and Kettaneh (2011) implies that competent exportercontributes to export performance. Researchers have shown that the good reputation of a firm enhances sales in existing markets (Shapiro, 1983; Kreps and Wilson, 1982; Milgrom and Roberts, 1982). It also reduces business risks, (Orlitzky and Benjamin, 2001) and assists in new market development and growth (Bromley, 2002). The study by Abd-El-Salam et al., (2013) implies that high service quality will lead to higher satisfaction, and this in turn will produce greater willingness to recommend the organization. Zhang and Rezaee (2009) reported that reputable and credible firms have better 3-year net profit margins, return 
on equity, sales growth and are able to outperform the lower ratings firms by almost $20 \%$ in 3-year stock returns.

Quality is a crucial competency for companies in deriving competitive advantage. Quality product and service need to be in conformance to the required specification to satisfy the user's needs. It does not means increasing the total costs as achieving quality reduces rework, scarp, after sales services, while business benefits through repeated sales from customer satisfaction and economies of scale. Achieving quality is fundamental to competition in business in propelling it into new heights. A firm will benefit most through focusing on the key processes that provide their customers with products and services. Producers may measure the conformance quality, or degree to which the product or service was made according to the required specification. Customers on the other hand, may focus on the quality specification of a product or service, or compare it with those that are available in the marketplace (KimSoon, 2012).

Perceived quality is defined as "a consumer's evaluation of a brand's overall excellence based on intrinsic (e.g., performance) and extrinsic cues (e.g., brand name)" (Kirmani \& Baumgartner, 2000). Brand name is a commonly used extrinsic cue to infer and/or maintain quality perceptions and can represent an aggregate of information about a product (Richardson et al., 1994). According to Della-Bitta et al., (1981) “a strong brand name helps to control or stabilize the quality perceptions of a branded product even when its price is discounted". In addition, in a more recent study, Dodds et al., (1991) also found empirical support for the positive effect of brand name on quality perceptions.

Reputation is about the beliefs or opinions that are generally held about someone, a group of people or a company. In case of business, the reputation of a firm plays a very important role in the buying decisions of the target customers (Cretu and Brodie, 2007). An exporter may be reputable as a reliable supplier, delivering the goods of agreed quality and on time. Reputation may also include firm good reputation for service quality and employee competency. Customers switch, and the company sees declining revenue and poor reputation. Birou and Fawcett (1993) found product and service quality characteristics have positive effect on the decision to import.

Cavusgil and Zou (1994), Shoham, (1998, 1999) and Carneiro et al., (2011) emphasized that export performance is a multifaceted construct. This is due to the fact that the success of a firm, division, or export venture is usually communicated through the use of various perspectives and dimensions of measure of performance. The determinants of export performance are generally grouped into controllable and uncontrollable factors derived from the two theoretical bases. The internal determinants are justified through resource based theory while the external determinants by industrial organization theory (Kim-Soon, 2005; Zou and Stan, 1998).

Export promotion done through advertisements and sales promotion is intended to increase the consumer demand and increase export performance. The results of previous works on export promotion and performance have been inconsistent in the literature. Shoham (1999) reported that export promotion is positively related to export success. Export success is the extent to which the firm's economic and strategic objectives are achieved in respect to exporting a product through export marketing. Adapting promotion strategy assists exporters in consistently positioning themselves to segment the market of the country they targeted. On the other hand, Cavusgil and Zou (1994) found export promotion strategy is negatively related to export success. They argued that the negative relationship is due to the subjectivity of market interpretation of market situations resulting in inaccurate market assumption 
that leads to the inappropriateness and costly adaptation of marketing strategies. The tasks of carrying out oversea promotion are difficult and it is tedious to find a good fit meeting consumers' tastes and preferences. Promotion activities require substantial investment. This would also increases cost and subsequently results in the reduction of profits (Koksal and Kettaneh 2011; Teixeira, 2014).

\section{Methodology}

\section{Research framework and hypotheses}

A firm's tangible assets include financial resources and physical facilities, and the intangible ones include skill sets, reputation, brand names, information and goodwill, etc. controlled by a firm that enable the firm to conceive and implement strategies (Barney, 1991). The resource-based view of firm recognized the transferability of a firm's resource and capabilities as a critical determinant of their capacity to confer sustainable competitive advantage. The transferability is important between firms and within the firm and is critical for success (Grant, 1996). Basing on this underlying theoretical ground, the research framework for this study has been proposed as in Figure 1 , where export promotion has an impact on the enhancement of a firm's quality reputation, product and service quality with sales and profits.

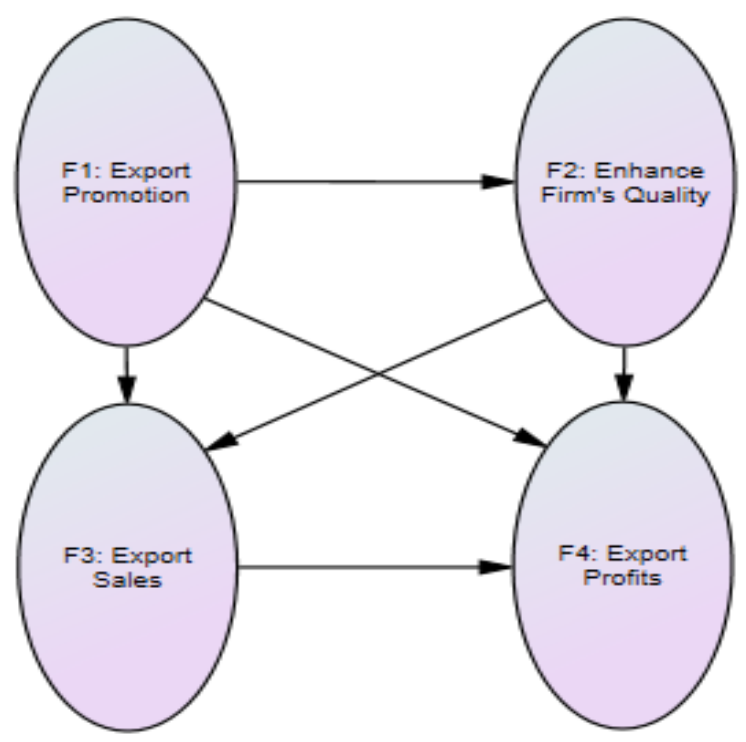

Figure 1: Research framework - Export promotion has impact on the enhancement of a firm's quality reputation, product and service quality generating sales and profits

The hypotheses that have been formulated based on this research framework are as follow:

H1a: Export promotion enhances firm's quality.

H1b: Export promotion enhances export sales performance
H1c: Export promotion enhances export profits.

H2a: Firm's quality enhancement has a positive impact on export sales.

H2b: Firm's quality enhancement has a positive impact on export profits.

H3: Export sales have a positive impact on export profits. 
H4a: Export promotion enhances firm's quality which will lead to higher sales.

H4b: Export promotion enhances firm's quality which will lead to higher profits.

H4c: Export promotion will lead to higher sales to generate higher profits.

\section{Survey Sample}

The population chosen for this study was from Malaysian manufacturing exporters from the state of Johor, Malaysia. The population frame is taken from a source published by the Federation of Malaysian Manufacturers (FMM) Directory 2012. Based on this FMM Directory, there are 362 manufacturing firms in Johor. However, the sample of this study was the identified Johor firms exporting their products to the foreign markets. Thus, a total of 230 which are manufacturing export firms were chosen. The sample size from the population was determined based on Krejcie and Morgan Table (Kejcie \& Morgan, 1970). Based on the Table, the research sample size was determined as 144 firms. However, only 48 companies responded to the survey with dully completed questionnaire and were used in the analysis. The respondent's profile and company background are shown in the Table 1.

Table 1: Profile of Responding Companies

\begin{tabular}{|c|c|c|}
\hline Demographic & Categories & Frequency \\
\hline \multirow[t]{3}{*}{ a. Education level } & Secondary School & 5 \\
\hline & Diploma/ Degree & 35 \\
\hline & Post Graduate Degree & 8 \\
\hline \multirow[t]{3}{*}{ b. Job position } & Top management & 7 \\
\hline & Management & 19 \\
\hline & Executive & 22 \\
\hline \multirow[t]{3}{*}{ c. Year of experience } & $<5$ & 15 \\
\hline & $5-<10$ & 13 \\
\hline & $10->10$ & 20 \\
\hline \multirow[t]{4}{*}{ d. Number of employees } & $<100$ & 14 \\
\hline & $100-<200$ & 12 \\
\hline & $200-<400$ & 11 \\
\hline & $>400$ & 11 \\
\hline \multirow[t]{3}{*}{ e. Company age } & $3-<10$ & 4 \\
\hline & $10-<20$ & 12 \\
\hline & $20->20$ & 32 \\
\hline \multirow[t]{3}{*}{ f. Year of exporting } & $3-<10$ & 7 \\
\hline & $10-<20$ & 15 \\
\hline & $20->20$ & 26 \\
\hline \multirow[t]{3}{*}{ g. Company ownership } & Local & 19 \\
\hline & Joint venture & 6 \\
\hline & Foreign & 23 \\
\hline \multirow[t]{3}{*}{ h. Percentage of product exported } & $<15 \%$ & 2 \\
\hline & $15-<50 \%$ & 17 \\
\hline & $>50 \%$ & 29 \\
\hline \multirow[t]{3}{*}{ i. Number of countries exported to. } & $<10$ & 34 \\
\hline & $10-<20$ & 6 \\
\hline & $>20$ & 8 \\
\hline j. Type of industry & Electrical and electronic & 6 \\
\hline
\end{tabular}

Ng Kim-Soon, Abd Rahman Ahmad and Chua Pei Shy (2016), Journal of Southeast Asian Research, DOI: $10.5171 / 2016.309540$ 


\begin{tabular}{|c|c|c|}
\hline & Machinery and engineering & 6 \\
\hline & Building and construction materials & 5 \\
\hline & Chemicals and chemical product & 5 \\
\hline & Rubber and plastic products & 4 \\
\hline & Iron, steel and basic metals & 4 \\
\hline & Packaging, labeling and printing & 4 \\
\hline & Food products and beverages & 3 \\
\hline & Wood based products & 6 \\
\hline & Equipment & 2 \\
\hline & Automotive & 1 \\
\hline & Others & 2 \\
\hline
\end{tabular}

\section{Survey measures}

There are 4 variables in the research framework. The measure for promotion adaptation (10 items) was adapted from Chung, Wang, \& Huang (2011), firm's quality enhancement (8 items) adapted from Cadogan et al., (2012); Ruzo et al., (2011) and Sousa (2004), export sales (5 items) and profits (3 items) from Souza (2004). The items were measured using a five-point Likert scale. For promotion adaptation, $1=$ very low to $5=$ very high adaptation and for the measures on firm's quality enhancement, sales and profits, respondent indicate their respective last three years firm's performance as compared to the performance of their main competitor in the export market on the scale where $1=$ much worst to $5=$ much better. The reliability tests using Cronbach Alpha for these measures are: export promotion is 0.922 , firm's quality enhancement is 0.853 , export sales are 0.928 and profits are 0.926 . Cronbach's Alpha value of greater or equal 0.7 indicated that the measures are reliable (Nunnally, 1978). Thus, all the measures are valid and reliable. The data set was tested for normality using one-sample Kolmogorov-Smirnoc Test. All the results of the variables were insignificant indicating that measures for the data collected are normally distributed.

\section{Results}

Analysis of Moment Structures (AMOS) was used to test the hypotheses of the causal relationship of the research framework formulated in accordance to the theories through model fit of establishment, estimation and tests of the causal relationships. The normality distribution of the items of this study was also checked through the AMOS software. Figure 2 shows the final estimation of the structural equation path diagram of the relations between export promotion, exporter's reputation, product improvement, service quality, sales and profits and its respective latent variables. The observed variables are in oval shape and the latent variables are represented by the respective boxes. The model fit values are: a. Tests for discrepancy function: chi-square test value of the model is 43.296 , CMIN/DF is 1.139 at $\mathrm{p}=0.256$, RMSEA $=0.045$ and PCLOSE value $=0.235$; $b$. Tests that compare the target model with the null model: $\mathrm{GFI}=0.893$, $\mathrm{NFI}=0.887, \mathrm{IFI}=0.985, \mathrm{TLI}=0.997, \mathrm{CFI}=0.984$. The chi-square value is not significant which indicates that the model is acceptable where the observed covariance matrix is similar to the predicted covariance matrix. RMSEA is the square root of the average of the covariance residuals where a zero means a perfect fit. Its value should be less than 0.08 (Brown \& Cudeck, 1993) and ideally $<0.05$ (Steiger, 1990). The closer the value of GFI, NFI, IFI, TLI, CFI approach to the value of 1 , the better is the degree of fit of the model. Thus, the model achieved fitness and is acceptable. 


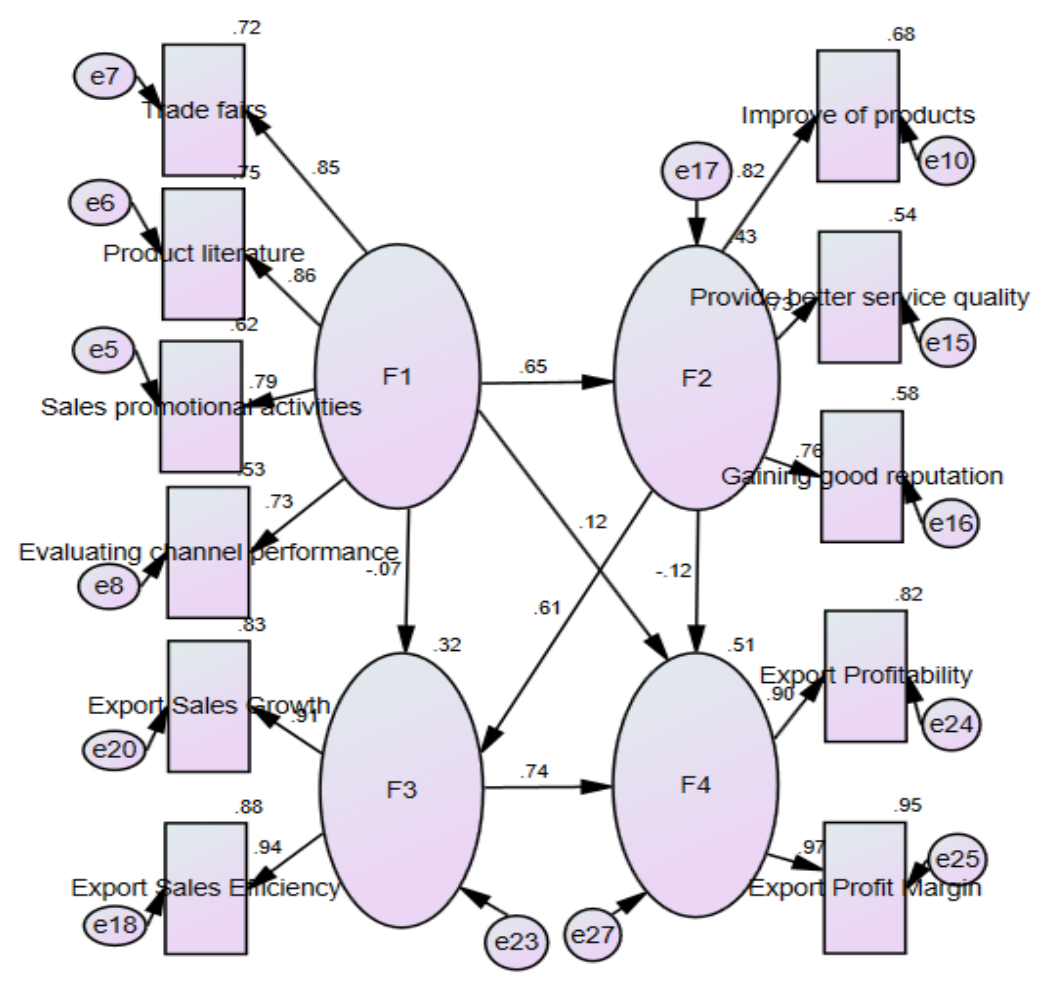

Figure 2: Path diagram of relationships between export promotion, exporter's reputation, product improvement, service quality, sales and profits

Note: Standardized estimates with bootstrapping

Variables: F1: Export promotion

F2: Firm's quality enhancement

F3: Export sales

F4: Export profits

Table 2 shows the results of estimates of the coefficient for indirect, direct and total effects of the causal relationships among the observed variables. Based on the analyses, the research hypotheses were validated and Table 3 summarizes the results. 
Table 2: The coefficient for indirect, direct and total effects of the causal relationships

\begin{tabular}{|c|c|c|c|c|}
\hline & & $\begin{array}{l}\text { F1: Export } \\
\text { promotion }\end{array}$ & $\begin{array}{c}\text { F2: Firm's quality } \\
\text { enhancement }\end{array}$ & F3: Export Sales \\
\hline \multirow{3}{*}{$\begin{array}{l}\text { F2: Firm's quality } \\
\text { enhancement }\end{array}$} & Indirect & & & \\
\hline & Direct & $0.655^{* * *}$ & & \\
\hline & Total & $0.655^{* * *}$ & & \\
\hline \multirow[t]{3}{*}{ F3: Export sales } & Indirect & 0.402 & & \\
\hline & Direct & -0.073 & $0.614^{* *}$ & \\
\hline & Total & 0.329 & $0.614^{* *}$ & \\
\hline \multirow[t]{3}{*}{ F4: Export profits } & Indirect & 0.163 & 0.456 & \\
\hline & Direct & 0.116 & -0.124 & $0.743^{* * *}$ \\
\hline & Total & 0.279 & 0.332 & $0.743^{* * *}$ \\
\hline
\end{tabular}

Note: Standardized estimate using bootstrapping; ${ }^{* *} \mathrm{p}<0.01,{ }^{* * *} \mathrm{p}<0.001$

Table 3: Summary of the results of results of the hypotheses tested

\begin{tabular}{|c|c|c|}
\hline Hypothesis & Path & Result \\
\hline H1a: Export promotion enhances firm's quality enhancement & F2<---F1 & Supported \\
\hline H1b: Export promotion enhances export sales performance & F3<---F1 & $\begin{array}{c}\text { Not } \\
\text { supported }\end{array}$ \\
\hline H1c: Export promotion enhances on export profits. & F4<---F1 & $\begin{array}{c}\text { Not } \\
\text { supported }\end{array}$ \\
\hline $\begin{array}{l}\text { H2a: Firm's quality enhancement has a positive on impact } \\
\text { export sales. }\end{array}$ & F3<---F2 & Supported \\
\hline $\begin{array}{l}\text { H2b: Firm's quality enhancement has a positive impact on } \\
\text { export profits. }\end{array}$ & F4<---F2 & $\begin{array}{c}\text { Not } \\
\text { supported }\end{array}$ \\
\hline H3: Export sales have a positive impact on export profits. & F4<---F3 & Supported \\
\hline $\begin{array}{l}\text { H4a: Export promotion enhances firm's quality which will lead } \\
\text { to higher sales. }\end{array}$ & $\begin{array}{c}\text { F3<---F2<--- } \\
\text { F1 }\end{array}$ & Supported \\
\hline $\begin{array}{l}\text { H4b: Export promotion enhances firm's quality which will lead } \\
\text { to higher profits. }\end{array}$ & $\begin{array}{l}\text { F4<---F2<--- } \\
\quad \text { F1 }\end{array}$ & $\begin{array}{c}\text { Not } \\
\text { supported }\end{array}$ \\
\hline $\begin{array}{l}\text { H4c: Export promotion will lead to higher sales to generate } \\
\text { higher profits. }\end{array}$ & $\begin{array}{l}\text { F4<---F3<--- } \\
\text { F1 }\end{array}$ & $\begin{array}{c}\text { Not } \\
\text { supported }\end{array}$ \\
\hline
\end{tabular}

\section{Discussion}

The research model formulated and analyzed has revealed the path relationships of export promotion, exporter's reputation, product improvement, service quality, export sales and profits in a clear manner. The latent variables are connected to these observable variables in one model and manifested their relationships among the variables offering

Ng Kim-Soon, Abd Rahman Ahmad and Chua Pei Shy (2016), Journal of Southeast Asian Research, DOI: $10.5171 / 2016.309540$ 
interpretation of the dependencies. The causal paths include the standardized estimates for the indirect as well as the direct effects with indication of the statistical significance of the respective relations, thus allowing the mediator the relationships to be interpreted of its mediating effects (Imai et al., 2010). Although the sample size for this research work is only 48 exporting firms, the indices of analyses indicated a good fitting model. CFI is preferred over GFI for small sample size (Wang et al., 1996). Tucker Lewis Index (TLI) is relatively independent of sample size (Marsh et al., 1988). The CFI, GFI and TLI for the final path model of relationships between export promotion with enhancement of firm's reputation, improvement and service quality, sales and profits and its respective latent variables are all acceptable. These have indicated that it is a good fitting model.

The latent variables are highly loaded with values greater than 0.7 into the observable variable of export promotion. These latent variables are management of sales promotion activities, selecting and participating in relevant trade fairs, preparation of product literature, and evaluating of channel performance. The tested model indicates that export promotion shows signification direct effect or strength of 0.655 on firm's quality enhancement. The latent variables that have loaded highly into firm's quality enhancement are improving products, providing better service quality and gaining in reputation. Kim-Soon and Jantan, (2010) found that there are significant differences in firm's quality levels of exporting firms and non-exporting. Exporting firms have higher system quality levels as compared to non-exporting firms. Ahmed (2010) found that the reputation of partners and marketing competencies of partners are significantly related to contractual and competence trust. In other words, firm reputation and competencies of partner are related to trust and commitment. Ahmed argued that they are also related to the interpersonal factors like effective communication, cultural sensitivity and likability of partners. These has indirectly provides an explanation to the result obtained from firm's quality enhancement. Service quality characteristics have in fact the greatest overall total effect upon trust (Chryssochoidis and Theoharakis, 2004). Wilson (1985) iterated that delivery, product and or service performance are central to the buyer's evaluation of the score as supplier performance (Wilson, 1985). A high reputation may lead to a corresponding level of trust (Backhaus and Voeth, 2007). Firms should select reliable international partners that possess better reputation. Boyd and Mason (1999) corroborated that the manufacturer's reputation affects the attractiveness of the product and purchase intention. Thus, supporting the finding that firm's quality enhancement enhances export sales.

In this study, the latent variable of sales performance that loaded in the observable measure of export sales is export sales efficiency and export sales growth. Sales efficiency is about promptness of handling tasks of the sales process. As for sales growth, it is how well the exporter improved the sales over a given time. It is an indication of whether the current way of doing sales is being carried out effectively. Thus, export sales here are a measure of sales efficiency and effectiveness. This research work shows that firm's quality enhancement has a positive impact export sales. Improving products, better quality services and gaining of reputation could increase sales efficiency and effectiveness. Product improvement could lead to improved product packaging. Technically, among the recent innovations in packaging is the development of active, passive, intelligent and interactive packaging (Singh and Heldman, 2014). Packaging is able to send out specific messages. When products are displayed in the shelves of stores, they attract different customers' attention through their specific messages. Chou and Wang (2012) reported that packaging has been used for identifying products, distinguishing them from the competitor's products, displaying the 
products' specific features and advantages; and boosting purchases. Koutsimanis et al., (2012) reported that studies show that product packaging strongly influenced the purchasing decisions of consumers. Auttarapong (2012) emphasized that packaging creates brand image and translates to manufacturer's reputation. Packaging attracts consumers' perception of products and facilitates the promotion of products. It is self-adverting through good package designs improving sales and market shares (Chou and Wang, 2012).

\section{Conclusion}

The export business performance is defined as the success or failure of the efforts made by an enterprise or a country in bringing its goods and/or services to penetrate the market of other countries. This may be measured through such indicators as sales figures, profits, marketing scales or other subjective measuring tools, or customer satisfaction (Nguyen, 2012). The exporters' goal is to obtain better export business performance in the export market. In this research, the profitability measures are found to comprise of export profits and export margin. Export sales have been found to have a positive impact on export profits. Adapting promotion supports the exporters to position at the market segment they target. However, the finding discloses that export promotion does not lead to sales and profits and that firm's quality enhancement does not lead to profitability. Export sales and profitability have been widely used to measure export performance, but export sales might not have a positive relationship with export profitability as the firms may reduce the price to increase the sales' volume and in this term will decrease the export profit (Lengler et al., 2013). Exporters could also be exporting at variable cost to support their operation without generating the profits. Promotion requires investment and it increases the cost that lowers the profit.
Thus, improvement in one dimension could be a trade-off for the other.

\section{Implications of study}

This research work is in line with evaluation by Sousa (2004) who expressed that export performance assessment is often idiosyncratic firm types and its setting. Sousa suggested that adoption of a contingency approach in the selection of individual export performance measures is to address the idiosyncrasies instead of taking a dogmatic view This peculiar nature echoes the called by Leonidou et al., (2013), and Zeriti et al., (2014) who reinforce the suggestion to use contingency approach for research in export marketing mix with performance.

Exporters should seek to build a good reputable foundation through promotion activities over time. This calls attention to company features and gives a wider scope for exporters to build customers' base, retaining them besides synthesizing enhancement of exporter's products and services quality. The strengthening of firm's quality of reputations, improvement in product and service quality contribute to export sales efficiency and growth. As firm's quality of reputation gets firmer, product improved and service quality enhanced, the business expands, export sales' efficiency and export sales grow. Taking other aspects of firm's strategy into account, firms should generate export profits and the required profit margin through using a sound export promotion strategy.

\section{Acknowledgement}

This research paper publication is supported by Universiti Tun Hussein Onn Malaysia (UTHM) under Grant Number C043 to Ng Kim-Soon. The authors wish to thank the respondents who have spent their precious time and patience for participating in this academic research project. 


\section{Reference}

1.Abd-El-Salam, E.M., Shawky, A.Y. and ElNahas, T. (2013). The impact of corporate image and reputation on service quality, customer satisfaction and customer loyalty: testing the mediating role. Case analysis in an international service company. The Business \& Management Review, Vol.3 (2), 177-196.

2. Ahmed, F. (2010). The role of interpersonal and firm factors in international business relationships, Asian Academy of Management Journal, Vol. 15(1), 45-62.

3. Auttarapong, D. (2012). Package design expert system based on relation between packaging and perception of customer. Procedia Engineering, Vol. 32, 307-314.

4. Backhaus, K. and Voeth, M. (2007). Industriegütermarketing. (8th ed.). München: Vahlen. Boyne, G.A. (2002). Public and Private Management: What's the Difference? Journal of Management Studies, Vol. 39(1), 97-122.

5. Barney, J. (1991). Firm resources and sustained competitive advantage. Journal of Management, March, Vol. 17, 100-120.

6. Birou L. and Fawcett S. (1993). International purchasing: benefits, requirements, and challenges. International Journal of Purchasing Materials Management, Vol. 1, 28 - 37

7. Boyd, T.C. and Mason, C.H. (1999). The link between attractiveness of "extra brand" attributes and the adoption of innovations, Academy of Marketing Science. Vol. 27 (3), 306-319.

8. Bromley, D.B. (2002). An Examination of Issues that Complicate the Concept of Reputation in Business Studies, International Studies of Management and Organization, Vol. 32(3), 65-81.

9. Browne, M.W., and Cudeck, R. (1993). Alternative ways of assessing model fit. In
Bollen, K. A. \& Long, J. S. (Eds.), Testing structural equation models (pp. 136-162). Newsbury Park, CA: Sage.

10. Cadogan, J.W., Sundqvist, S., Puumalainen, K. and Salminen, R,T. (2012). Strategic flexibilities and export performance. The moderating roles of export market-oriented behavior and the export environment. European Journal of Marketing, Vol. 46(10), 1418-1452.

11. Carneiro, J., Rocha, A.D. and Silva, J.F.D. (2011). Determinants of export performance: a study of large brazilian manufacturing firms. BAR - Brazilian Administration Review, Vol. 8(2), 107-132. Retrieved from http://www.redalyc.org/articulo.oa?id=8411 8476002

12. Cavusgil, S., and Zou, S. (1994). Marketing strategy-performance relationship: An investigation of the empirical link in export market ventures. Journal of Marketing, Vol. 58(1), 1-21.

13. Chou, M.C., and Wang, R.W. (2012). Displayability: An assessment of differentiation design for the findability of bottle packaging. Displays, Vol. 33(3), 146156.

14. Chryssochoidis, G. and Theoharakis, V. (2004). Attainment of competitive advantage by the exporter-importer dyad: The role of export offering and import objectives, Journal of Business Research, Vol. 57, 329-337.

15. Chugan, P.K., and Singh, S. (2014). Taxonomy for Measurement of Firm-level Export Performance, Universal Journal of Industrial and Business Management Vol. 2(8), 193-199, http://www.hrpub.org DOI: 10.13189/ujibm.2014.020801

16. Chung, H.F., Wang, C.L., and Huang, P.H. (2012). A Contingency Approach to International Marketing Strategy and Decision-Making Structure Among Exporting Firms. International Marketing Review, Vol. $29,77$. 
17. Cretu, A.E. and Brodie, R.J. (2007). The influence of brand image and company reputation where manufacturers market to small firms: A customer value perspective. Industrial Marketing Management, Vol. 36(2), 230-240.

18. Darke, P.R., and Dahl, D.W. (2003). Fairness and Discounts: the Subjective Value of a Bargain. Journal of Consumer Psychology, 13(3), 328-338.

19. Della-Bitta, A., Monroe, K.B. and McGinnis, J.M. (1981). Consumer Perceptions of Comparative Price Advertisements. Journal of Marketing Research, Vol. 18, 416-427.

20. Dodds, W.B., Monroe, K.B., and Grewal, D. (1991). Effects of Price, Brand and Store Information on Buyers' Product Evaluation. Journal of Marketing Research, Vol. 28(3), 307-319.

21. Ehrman, C. (2011). Toward Finding an Optimal Mix between Push and Pull Strategies: Try Conjoint Analysis. The Journal of American Academy of Business, Vol. 17(1), 196-201.

22. Grant, R.M. (1996). Towards a knowledge-based theory of the firm. Strategic Management Journal, Winter Special Issue, 17, 109-122.

23. Imai, K., Keele, L. and Tingley, D. (2010). A general approach to causal mediation analysis, Pshchological Methods, Vol. 15(4), 309-334.

24. Kim-Soon, N. (2012). Quality Management System and Practices. In KimSoon Ng (Ed.), Quality Management and Practices, InTech, Croatia, IBSN 987-953-510550-3.

25. Kim-Soon, N. and Jantan, M. (2010). Quality Management Practices in Malaysia: Perceived Advancement in Quality Management and Business Performance. Proceedings of the 2010 IEEE ICMIT, Singapore, 263-268.
26. Kim-Soon, N. (2005). Value of Export Information, Export Marketing Competencies, Environmental Characteristics and Export Venture Performance, PhD. Theses, Universiti Sains Malaysia, School of Business Studies, Malaysia.

27. Kirmani, A. and Baumgartner, H. (2000). Reference Points Used in Quality and Value Judgments. Marketing Letters, Vol. 11(4), 299-310. http://dx.doi.org/10.1023/A:100812901120 2

28. Koksal, M.H., and Kettaneh, T. (2011). Export Problems Experienced by High and Low Performing Manufacturing Companies. Asia Pacific Journal of Marketing and Logistics, Vol. 23, 118.

29. Koutsimanis, G., Getter, K., Behe, B., Harte, J. and Almenar, E. (2012). Influences of packaging attributes on consumer purchase decisions for fresh produce, In: Yeomans, M. (ed.), Appetite, The 36th Annual Meeting of the British Feeding and Drinking Group, Vol. 59, No. 2, Elsevier, 270-280, doi: 10.1016/j.appet.2012.05.012.

30. Krejcie, R.V. and Morgan, D.W. (1970). Determining Sample Size For Research Activities. Education and Psychological measurement.

31. Kreps, D.M. and R. Wilson (1982). Reputation and Imperfect Information, Journal of Economic Theory, Vol. 27(2), 253279. doi:10.1016/0022-0531(82)90030-8.

32. Lages, C., Lages, C.R. and Lages, L.F. (2005). The RELQUAL scale: a measure of relationship quality in export market ventures. Journal of Business Research, 58, 1040-1048.

33. Lengler, J.F., Sousa, C.M., and Marques, C. (2013). Exploring the Linear and Quadratic Effects of Customer and Competitor Orientation on Export Performance. International Marketing Review, Vol. 30, 447. 
34. Marsh, H.W., Balla, J.R. and McDonald, R.P. (1988). Goodness-of-fit indexes in confirmatory factor analysis: The effect of sample size. Psychological Bulletin, Vol. 103, 391-410.

35. Milanzi, M.A. (2012). The Impact of Barriers on Export Behavior of a Developing Country Firms: Evidence from Tanzania, International Journal of Business and Management, Vol. 7(3), 10-21. doi:10.5539/ijbm.v7n3p10

36. Milgrom, P. and Roberts, J. (1982). Predation, Reputation and Entry Deterrence, Journal of Economic Theory, Vol. 27(2), 280312. doi:10.1016/0022-0531(82)90031-X

37. Nguyen, H. (2012). International marketing capacities and export performance: an empirical study of indochinese exporting enterprises. International journal of marketing studies, Vol. 4, 52.

38. Nunnally, J.C. (1978). Psychometric Theory, $2^{\text {nd }}$ ed., McGraw-Hill, New York, NY.

39. Okoroafo, S.C. and Perryy, M. (2010). Generational Perspectives of the Export Behavior of Family Business. International Journal of Economics and Finance, Vol. 2, 18.

40. Orlitzky, M. and Benjamin, J. D. (2001). Corporate Social Performance and Firm Risk: A Meta-Analytic Review, Business \& Society, Vol. 40(4), 369-396. doi:10.11 77/000765030104000402.

41. Raghubir, P. (2004). Free Gift with Purchase: Promoting or Discounting the Brand? Journal of Consumer Psychology, Vol. 14(1/2), 181-186.

42. Ruzo, E., Losada, F., Navarro, A., and Diez, J. A. (2011). Resources and international marketing strategy in export firms. Implications for export performance. Management Research Review, Vol. 34(5), 496-518.
43. Richardson, P.S., Dick, A.S. and Jain, A.K. (1994). Extrinsic and Intrinsic Cue Effects on Perceptions of Store Brand Quality. Journal of Marketing, Vol. 58(October), 28-30.

44. Shamsuddoha, A.K. and Ali, M.Y. (2006). Mediated effects of export promotion programs on firm export performance, Asia Pacific Journal of Marketing and Logistics, Vol. 18(2), 93-110.

45. Shapiro, C. (1983). Premiums for High Quality Products as Returns to Reputations, The Quarterly Journal of Economics, Vol. 98(4), 659-679. doi:10.2307/1881782.

46. Shoham, A. (1998). Export performance: a conceptualization and empirical assessment. Journal of International Marketing, Vol. 6(3), 59-81.

47. Shoham, A. (1999). Bounded rationality, planning, standardization of international strategy, and export performance: A structural model examination. Journal of International Marketing, Vol. 7(2): 24-50.

48. Singh, R.P. and Heldman, D.R. (2014). Chapter 15 - Packaging concepts, In: Introduction to food engineering, 5th edition, Academic Press, 767-791, doi: 10.1016/B978-0-12-398530-9.00015-2.

49. Sousa, C.M.P. (2004).Export performance measurement: An evaluation of empirical research in the literature. Academy of Marketing Science Review, Vol. 9, 1-23.

50. Steiger, J.H. (1990). Structural model evaluation and modification: An interval estimation approach. Multivariate Behavioural Research, 25, 173-180.

51. Teixeira, T.S. (2014). Harvard Business School. The rising cost of consumer attention: Why you should care, and what you can do about it. Retrieved on April 18, 2014, from http://hbswk.hbs.edu/workingpapers. 
52. Wang, L., Fan, X. and Willson, V. (1996). Effects of non-normal data on parameter estimates and fit indices for a model with latent and manifest variables: An empirical study. Structural Equation Modeling, Vol. 3, 228-247.

53. Wilkinson, T.J. and Brouthers, L.E. (2006). Trade promotion and SME export performance, International Business Review, Vol. 15(3), 233-352.

54. Wilson D.T. (1985). An integrated model of buyer - seller relationships. Journal of the Academy of Marketing Science, Vol. 23, $335-45$.

55. Wong, H. and Merrilees, B. (2007). Closing the marketing strategy to performance gap: The role of brand orientation, Journal of Strategic Marketing, Vol. 15(5), 387-402.

56. Zeriti, A., Robson, M.J., Spyropoulou, S., and Leonidou, C.N. 2014. Sustainable export marketing strategy fit and performance. Journal of International Marketing, 22(4): 4466.

57. Zhang, R. and Rezaee, Z. (2009). Do Credible Firms Perform Better in Emerging Markets? Evidence from China, Journal of Business Ethics, Issue 90, 221-237. DOI 10.1007/s10551-009-0038-8

58. Zou, S. and Stan, S. (1998). The determinants of export performance: a review of the empirical literature between 1987 and 1997, International Marketing Review, Vol. 15, 333-356. 